\title{
FUNGSI LEMBAGA PERLINDUNGAN ANAK SUMATERA BARAT DALAM MELAKUKAN PERLINDUNGAN TERHADAP ANAK YANG TERJERAT KASUS TINDAK PIDANA
}

\author{
TRIADI
}

Sekolah Tinggi Ilmu Hukum Padang

\begin{abstract}
Abtrak: Berdasar hasil penelitian dan pembahasan dapat disimpulkan bahwa bentuk penyelesaian secara kekeluargaan/perdamaian atau non-litigasi adalah dengan cara muyawarah antara pelaku, korban, keluarga pelaku atau keluarga korban serta disaksikan oleh pihak LPA dan Polisi sebagai mediator. Penyelesaian secara kekeluargaan/perdamaian atau non-litigasi dilakukan dengan alasan : menghindari stigmatisasi pelaku sudah menyadari kesalahannyapihak korban sudah memperoleh ganti rugi dari pelakutindak pidana yang dilakukan pelaku ringan Penyelesaian secara non litigasi dapat memenuhi dan mencapai perlindungan terhadap anak yang melakukan tindak pidana, karena : saling memaafkan antar pelaku dan korbananak pelaku tindak pidana kembali ke orang tuatercapai keseimbangan dalam masyarakatsudah tidak ada stigma bagi anak. Namun demikian, penyelesaian nonlitigasi ini juga memiliki beberapa kendala dalam praktik pelaksanaannya yakni: pihak korban tidak mau menerima penyelesain secara non litigasitindak pidana yang dilakukan diancam dengan pidana berataparat penegak hukum kurang mendukung tidak ada juklak atau juknis untuk pelaksanaannya.
\end{abstract}

Kata Kunci: Lembaga Perlindungan Anak, Sumatera Barat, Tindak Pidana

\section{A. Pendahuluan}

Upaya Perlindungan Anak di Sumatera Barat dilakukan atas respon terhadap kondisi kehidupan anak-anak di masa krisis ekonomi pada akhir 1998. Pada waktu itu difasilitasilah kelahiran lembaga lembaga perlindungan anak baik itu lembaga atas inisiatif masyarakat atau yang saat ini kita kenal dengan NGO atas LSM , lembaga yang berdiri atas inisiatif pemerintah seperti Lembaga Perlindungan Anak (LPA) maupun yang didirikan langsung oleh pemerintah atau Pemerintah Daerah seperti Rumah Sosial Perlindungan Aanak (RSPA).LPA yang difasilitasi oleh Kanwil Departemen Sosial Propinsi Sumatera Barat (pada waktu itu). Walaupun sejarah pendiriannya begitu dekat dengan Departemen Sosial, tapi pada pengelolaanya diserahkan langsung kepada masyarakat/individu yang peduli terhadap kehidupan anak di Sumbar dan memang pada periode kepengurusan 1998-2001, kepengurusan LPA Sumbar terdiri dari tokoh-tokoh yang "concern" memperjuangkan hak anak di Sumatera Barat. Dan pendirian LPA di seluruh propinsi di Indonesia tidak lepas dari Surat Keputusan Menteri Sosial No. 81/HUK/1997 tertanggal 5 Desember 1997 perihal pembentukan wadah perlindungan Anak yang dinamakan dengan Lembaga Perlindungan Anak (LPA). Lembaga ini pertama kali didirikan di Jakarta dan kemudian diikuti oleh propinsi-propinsi lain sebagai konsekuensi diberlakukannya Surat Keputusan tersebut. Sementara di Propinsi Sumatera Barat kepengurusannya diperkuat dengan Surat Keputusan Gubernur Sumbar tentang pengukuhan kepengurusan LPA Sumbar Nomor263-248-2008. Saat ini LPA Sumbar berafiliasi langsung dengan Komisi Nasional Perlindungan Anak (Komnas PA) dan berbagai kegiatan dan program. 
Walaupun pada waktu pendiriannya difasilitasi oleh Kanwil Sosial Sumatera Barat dan berafiliasi dengan Komnas Perlindungan Anak,tetapi dalam pelaksanaan dan pengambilan keputusan organisasi diserahkan langsung secara otonom kepada pengurus yang berasal dari masyarakat luas. LPA Sumbar saat ini telah disyahkan berdasarkan akte notaris yang dikeluarkan oleh Riri Indriyani, SH. SK Menhukham RI No. C-699.HT.03.01-TH-2004. ,Adapun mengenai Visi dan Misinya adalah "Memperjuangkan pemenuhan hak-hak anak sebagai bagian dari hak asasi manusia" dengan Misinya : Memperjuangkan pemenuhan hak-hak anak melalui pengembangan komunitas anak. Pemberdayaan dan penguatan masyarakat sipil yang peduli dan mengedepankan kepentingan terbaik bagi anak. Advokasi kebijakan publik mengenai pemenuhan dan perlindungan hak-hak anak. Membangun jaringan kerjasama dalam usaha memperkuat kapasitas kelembagaan dalam memperjuangkan pemenuhan hakhak anak. Dalam pergerakannya LPA mempunyai Strategi Program dengan Mengingat begitu pentingnya persoalan hak anan untuk dikelola di Sumatera Barat, maka LPA Sumbar menetapkan beberapa strategi program kedepan.

Persoalan anak menjadi persoalan yang sangat fenomenal akhir-akhir ini , terutama sekali pada tahun 2015 yang lalu. Baik anak yang menjadi korban perbuatan pidana maupun anak yang melakukan perbuatan pidana. Salah satu persoalan besar dalam pemidanaan terhadap anak adalah efek buruk pemidanaan terhadap perkembangan anak. Pemidanaan kerap mendatangkan cap buruk pada seseorang, yang dalam konteks anak, akan amat destruktif terhadap kehidupannya yang masih panjang diharapkan. Penyelesaian non-penal menjadi ide yang mengemuka yang kerap lebih disukai para pihak. Di pihak pelaku, stigmatisasi bisa dihindarkan, sementara pihak korban mendapat kepuasan dengan kompensasi dan atau kesepakatan tertentu dengan pelaku. Alih-alih dipidanakan, pelaku dikembalikan pada orang tuanya, sedangkan korban -misalnya-mendapatkan ganti rugi tertentu dan permohonan maaf. Kendati penyelesaian melalui jalur non-litigasi ini tidak selalu disepakati terutama oleh pihak korban, namun penyelesaian seperti ini terbukti banyak dipilih oleh pihak-pihak yang berkonflik. Artikel ini merekomendasikan diproduksinya peraturan perundangan yang memberikan kepastian hukum dalam penyelesaian melalui jalur non-litigasi ini.Dengan dikeluarkannya Undang-Undang 11 tahun 2012 tentang Sistem Peradilan Pidana Anak maka penyelesaian perkara anak yang berhadapan dengan Hukum tersebut dikenal dengan Diversi

Setiap anak memerlukan pembinaan dan perlidungan dalam rangka menjamin pertumbuhan dan perkembangan fisik, mental dan sosial secara utuh, serasi, selaras dan seimbang. Pembinaan dan perlindungan anak ini tak mengecualikan pelaku tindak pidana anak, kerap disebut sebagai "anak nakal". Anak yang melakukan tindak pidana, dalam hal ini sebagaimana ditentukan dalam pasal 1 (1) UU No. 11 tahun 2012 tentang Sistem Peradilan Pidana Anak, ialah orang yang telah mencapai 12 tahun tetapi belum mencapai 18 tahun dan belum pernah kawin. Dalam konteks hukum acara pidana, Sudarto (1980) menegaskan bahwa aktivitas pemeriksaan tindak pidana yang dilakukan oleh polisi, jaksa, hakim dan pejabat lainnya haruslah mengutamakan kepentingan anak atau melihat kriterium apa yang paling baik untuk kesejahteraan anak yang bersangkutan tanpa mengurangi perhatian kepada kepentingan masyarakat.

Sementara itu diyakini bahwa penjatuhan pidana terhadap anak nakal (delinkuen) cenderung merugikan perkembangan jiwa anak di masa mendatang (Paulus Hadisuprapto, 2003). Kecenderungan merugikan ini akibat dari efek penjatuhan pidana terutama pidana penjara, yang berupa stigma (cap jahat). Dikemukakan juga oleh Barda Nawawi Arief , pidana penjara dapat memberikan stigma yang akan terbawa E-ISSN: 2657-0300 Lembaga Penelitian dan Penerbitan Hasil Penelitian Ensiklopedia $\quad 281$ 
terus walaupun yang bersangkutan tidak melakukan kejahatan lagi (Barda Nawawi Arief, 2014). Akibat penerapan stigma bagi anak akan membuat mereka sulit untuk kembali menjadi anak "baik". Dalam kaitan ini, menurut Lembaga Perlindungan Anak Sumatera Barat bahkan mengemukakan, bahwa pidana penjara termasuk jenis pidana yang relatif kurang efektif. Berdasarkan hasil studi perbandingan efektivitas pidana, angka perbandingan rata-rata pengulangan atau penghukuman kembali (reconviction rate) orang yang pertama kali melakukan kejahatan berbanding terbalik dengan usia pelaku. Revonviction rate yang tertinggi, terlihat pada anak-anak, yaitu mencapai 50 persen. Angka itu lebih tinggi lagi setelah orang dijatuhi pidana penjara daripada pidana bukan penjara.

Sebuah penelitian yang dilakukan mengenai anak yang tersangkut dengan perkara hukum di wilayah BAPAS Sumatera Barat yang meliputi seluruh wilayah Sumatera Barat menunjukkan trend penyelesaian perkara tindak pidana yang dilakukan oleh anak-anak secara kekeluargaan (Wahyudi, Hapsari, 2019). Perkara tidak dilimpahkan ke pengadilan untuk diperiksa dan diputus oleh pengadilan dan praktik yang dikenal dengan penyelesaian non-litigasi. Penyelesaian konflik yang lebih banyak dikehendaki para pihak ini justru disarankan oleh penegak hukum maupun pihak Lembaga Perlindungan Anak (LPA) Sumatera Barat Hal ini dapat dilihat dari kondisi data di Lembaga Perlindungan Anak Sumatera Barat, sebagai berikut.

\begin{tabular}{|c|c|c|}
\hline Nomor & $\begin{array}{c}\text { Jenis Sanksi yang disarankan LPA untuk Klien dari tahun } \\
\text { 2017- Desember } 2019\end{array}$ & Jumlah \\
\hline 1 & Pidana bersyarat & 25 \\
\hline 2 & Pidana dengan pembimbingan/ pengawasan & 24 \\
\hline 3 & Pidana sesuai dengan perbuatan & 9 \\
\hline 4 & $\begin{array}{l}\text { Pidana dengan memperhatikan masa penahanan yang telah } \\
\text { dijalani }\end{array}$ & - \\
\hline 5 & Pendidikan Paksa ke Negara & - \\
\hline 6 & Agar dikembali ke Orang tua & 28 \\
\hline 7 & $\begin{array}{l}\text { Kekeluargaaan/ perdamaian atau } \\
\text { disaksikan oleh Bapas dan Kepolisian }\end{array}$ & 29 \\
\hline 8 & Pelimpahan ke Bapas & 16 \\
\hline
\end{tabular}

\section{Sumber LPA Sumbar 2019.}

Berdasar tabel di atas nampak bahwa pihak LPA mengusulkan kepada pihak pengadilan agar tidak semua perkara tindak pidana anak diselesaikan dan diputus di pengadilan. Sebagai gantinya penyelesaiannya adalah dengan: Anak diserahkan kembali kepada orang tua; Permasalahan diselesaikan secara kekeluargaan/ perdamaian atau Non-Litigasi yang disaksikan oleh LPA dan Kepolisian atau lebih dikenal dengan diversi ( pengalihan penyelesaian perkara Anak dari proses peradilan pidana ke proses di luar peradilan pidana.)

\section{B. Metdologi Penelitian}

Penelitia ini menggunakan penelitian hukum, yang akan melihat: 1) bagaimanakah fungsi Lembaga Perlindungan Anak Sumatera Barat dalam melakukan perlindungan terhadap anak yang terjerat tindak pidana. 2) bagaimanakah kendala yang ditemui dalam melaksanakan fungsi Lembaga Perlindungan Anak Sumatera Barat dalam melakukan perlindungan terhadap anak yang terjerat tindak pidana, dan 3) apa 
upaya yang dilakukan dalam mengatasi kendala tugas dan fungsi Lembaga Perlindungan Anak Sumatera Barat dalam melakukan perlindungan terhadap anak yang terjerat kasus tindak pidana.

\section{Hasil dan Pembahasan}

\section{Fungsi Lembaga Perlindungan Anak Sumatera Barat dalam Memberikan Perlindungan Anak Terhadap Anak Terjerat Kasus Pidana.}

Sebagai bentuk perlindungan anak dari segala tindak kekerasan, penelantaran, perlakuan salah, diskriminasi dan ekspoitasi, sejak tahun 1997 telah dibentuk Komisi Nasional Perlindungan Anak (KOMNAS PA), yang bersifat Independen dan memegang teguh prinsip non-diskriminasi, memberikan kepentingan terbaik bagi anak, melindungi kelangsungan hidup dan perkembangan anak serta menghormati pandangan anak. Kemudian sebagai tindak lanjutnya, di daerah dibentuk Lembaga Perlindungan Anak (LPA) melalui Kepmensos RI Nomor 81/HUK/1997 tanggal 5 Desember 1997 tentang Pembentukan Lembaga Perlindungan Anak (LPA) sebagai salah satu upaya masyarakat dalam melaksanakan sebagian tugas dan peran pemerintah untuk turut serta melaksanakan pemenuhan hak-hak anak dalam rangka perlindungan anak, sebagaimana yang terdeskripsikan dalam sejarah lahirnya Komisi Nasional Perlindungan Anak (Komnas PA) dan Lembaga Perlindungan Anak.

Upaya kemudian yang terus dikembangkan oleh Pemerintah dalam hal ini Departemen Sosial dalam memberikan dukungan dan perhatian guna peningkatan kapasitas LPA adalah dengan melaksanakan Capacity Building Petugas / Pekerja Sosial LPA dari daerah, mengingat keberadaan LPA di daerah-daerah sebagai lembaga independen yang mengutamakan kepentingan anak, melakukan usaha-usaha perlindungan anak, dan advokasi terhadap hak-hak anak Indonesia terdiri dari unsur sumber daya manusia yang berlatar belakang pendidikan dan pengalaman yang bervariasi. Dengan semakin kompleksnya permasalahan anak di Indonesia dan jumlahnya semakin bertambah dari waktu ke waktu, maka keberadaan LPA menjadi semakin strategis dan harus didukung oleh semua pihak. Setiap LPA dituntut untuk dapat berkoordinasi dan bekerja sama dalam penanganan kasus anak yang membutuhkan perlindungan khusus.

Disamping itu, menguatnya otonomi daerah dewasa ini, ternyata membawa perubahan pula terhadap keberadaan LPA di daerah. Hampir semua daerah, menempatkan petugas baru di LPA dan lebih dari 30\% dari instansi/lembaga lain belum memiliki pengalaman yang cukup dalam penanganan kasus anak yang membutuhkan perlindungan khusus. Akibatnya banyak kasus pelanggaran hak-hak anak yang sering mengalami keterlambatan penanganan dan tidak terselesaikan. Hal ini ditambah dengan kesulitan yang dialami oleh LPA dalam mengelola manajemen organisasi sehingga berpengaruh pada upaya perlindungan anak yang mereka lakukan.

Berkaitan dengan permasalahan di atas, dari hasil kegiatan Pengembangan Kapasitas Pekerja Sosial/Petugas LPA yang dilaksanakan selama 4 (empat) hari dari mulai tanggal 9 s/d 12 Juni 2009 diperoleh rujukan untuk ditindaklanjuti baik oleh Departemen Sosial, Komnas PA, maupun LPA adalah: 1) Memperkuat statuta kelembagaan Lembaga Perlindungan Anak baik di tingkat pusat mapun daerah, dengan melakukan review dan memberikan rekomendasi terhadap Keputusan Menteri Sosial RI No. 81/HUK/1997; 2) Memperbaiki kegiatan-kegiatan kelembagaan LPA terhadap langkah-langkah strategis dalam penanganan kasus-kasus kelembagaan LPA baik internal maupun eksternal; 3) Perumusan Standar Operasional Prosedur pelayanan dan manajemen Lembaga Perlindungan Anak; dan 4) Tersusunya rencana kerja (action E-ISSN: 2657-0300 Lembaga Penelitian dan Penerbitan Hasil Penelitian Ensiklopedia $\quad 283$ 
plan) Lembaga Perlindungan Anak terkait dengan program Departemen Sosial dan/atau Dinas Sosial.

Diktum Kedua Keputusan Komisi Nasional Perlindungan Anak (Komnas PA) tentang Kepengurusan Lembaga Perlindungan anak (LPA) Provinsi Sumatera Barat periode 2015-2020 sebagaimana dimaksud dalam diktum kesatu mempunyai Tugas Pokok sebagai berikut : mengumpulkan, mengolah, dan mengkaji data dan informasi yang berkaitan dengan masalah pelanggaran Hak-Hak Anak; melakukan Advokasi, untuk mendukung pembuatan kebijakan dan peraturan perundang-undangan yang berpihak kepada kepentingan anak; melakukan sosialisasi dan desiminasi Peraturan Perungang-undangan dan program kegiatan perlindungan anak; melakukan koordinasi bersama instansi / lembaga terkait untuk meningkatkan jaringan kemitraan dalam upaya perlindungan anak; melakukan bantuan tehnis dalam peningkatan kualitas petugas pelaksana program perlindungan anak; mengembangkan dan meningkatkan Forum Anak sebagai wadah partisipasi anak dalam upaya perlindungan anak; melakukan rujukan kasus ke pusat-pusat layanan seperti Puskesmas, Rumah Sakit, Pusat Pelayanan Terpadu/Pelayanan Tindak Kekerasan (PPT/PTK) Pelayanan Perempuan dan Anak (PPA), Rumah Perlindungan Sosial anak (RPSA), Lembaga Sosial masyarakat (LSM), Panti Asuhan dan lembaga lainnya, danmelakukan pemantauan terhadap pelaksanaan kegiatan perlindungan anak di wilayah Provinsi Sumatera Barat.

Lokasi penelitian di LPA Sumatera Barat, yang wilayah kerjanya meliputi Sumatera Barat dengan 19 (sembilan belas ) Kabupaten dan Kota . Salah satu kendala yang dihadapi adalah manakala informan dari anak yang melakukan tindak pidana dan pihak korban enggan untuk menceritakan kembali kasus yang menimpanya. Belum lagi kendala dari orangtua pelaku dan korban yang merasa malu anaknya melakukan tindak pidana. Namun demikian melalui pendekatan persuasif kendala ini dapat diatasi. Mengingat LPA memegang posisi sentral dalam upaya non-litigasi, maka akan dipaparkan hasil penelitian yang didapat di LPA.Sumatera Barat .

\section{Kendala Yang Ditemui dalam Melaksanakna Tugas dan Fungsi Lembaga Perlindungan Anak Sumatera Barat dalam Memberikan Perlindungan Terhadap Anak Terjerat Kasus Tindak Pidana}

Kendala Penanganan Masalah Perlindungan Anak oleh Lembaga Perlindungan Anak selama ini adalah sering terhenti di level kebijakan pemerintah daerah Kabupaten atau Kota serta saat penyidikan. Hal itu dikatakan oleh Ketua LPA Provinsi Sumatera Barat dan menjelaskan, pemerintah daerah diwajibkan melaksanakan enam tugas terkait isu pemberdayaan perempuan dan perlindungan anak. Berdasarkan Undang-Undang Nomor 23 Tahun 2014 tentang Pemerintahan Daerah, pemda wajib mengurus soal kualitas hidup perempuan, perlindungan perempuan, kualitas keluarga, sistem data gender dan anak, pemenuhan hak anak, dan perlindungan khusus anak.

Kenyataannya, seringkali dua urusan tersebut digabung dan ditangani oleh satu bidang. Misalnya, urusan perlindungan perempuan seharusnya ditangani oleh satu bidang, dan satu bidang lainnya menangani perlindungan khusus anak. Faktanya, kedua urusan kerap ditangani oleh satu bidang. Priyadi menambahkan, tugas tersebut akan semakin terhambat karena jumlah orang tidak sebanding dengan kasus yang ditangani. "Yang paling runyam adalah ketika urusannya banyak tapi yang menangani 
benar-benar sedikit sehingga tidak mampu, ini yang paling sering kita alami di perlindungan Anak ," kata Erry Gusman. Selain itu, ia juga mengungkapkan kekurangan anggaran menjadi penyebab utama terhambatnya penanganan isu-isu terebut. "Itu yang menjadi kenapa selama ini sering banyak hambatan-hambatan, ketika kita sampaikan itu, kepada daerah akan teriak, 'kami tidak punya anggaran', itu selalu," ujar Ketua LPA Sumatera Barat.

Demikian pula soal minimnya anggaran di LPA Sumatera Barat tersebut yang dialokasikan di APBN beberapa tahun lalu kemudian semenjak tahun 2017 hingga 2019 tidak ada lagi alokasi anggaran untuk LPA Sumatera Barat sedangkan di APBD Provinsi Sumatera Barat belum pernah dianggarkan untuk LPA Sumatera Barat . Ia mengatakan, anggaran kementerian Sosial tahun 2014 sebesar Rp. 30.000.000,- (tiga Puluh Juta Rupiah ) tahun 2015 sebesar Rp. 39.000.000,- ( tiga Puluh sembilan Juta Rupiah ) dan tahun 2016 sebesar Rp. 45.000.000,- ( empat puluh lima juta rupiah ).

Menurut Ketua LPA Sumatera Barat jumlah itu berbeda jauh dengan anggaran yang di pemerintah sendiri yang mencapai milyaran rupiah. Padahal, permasalahan anak yang mereka tangani kompleks dan memiliki cakupan luas, dari hulu ke hilir, sehingga membutuhkan dana yang besar. "Kasusnya banyak, namanya membangun peradaban supaya hak anak tidak diabaikan oleh siapapun, dalam penangan anak itu kan dari semua sektor, semua bidang. "Tidak bisa cuma menangani kasus saja yang diperbaiki, tapi pendidikannya tidak, kan tidak bisa, makanya itu perlu anggaran besar, perlu keberpihakan semua pihak diharapkan anggaran tahun berikutnya LPA juga menjadi perhatian pemerintah dan pemerintah daerah demi memaksimalkan kinerja LPA.

\section{Upaya Yang dilakukan Mengatasi Kendala dalam Melaksanakan Tugas dan Fungsi Lembaga Perlindungan Anak Sumatera Barat dalam Memberikan Perlindungan Anak Terhadap Terjerat Kasus Tindak Pidana}

Penyelesaian secara litigasi masih merupakan "primadona" bagi aparat penegak hukum. Hal ini dapat dimaklumi, karena seperti yang dinyatakan oleh Peter M. Blau dan Marshal W. Meyer (1987), birokrat terkadang tampil terlalu kaku. Fenomena ini terlihat dari jumlah tindak pidana yang dilakukan oleh anak yang diproses seperti dalam tabel 1 diatas . Dari tabel di atas diketahui bahwa dari 360 perkara yang dimintakan Litmas, perkara pencurian menempati urutan teratas sebanyak 213 perkara dengan persentase $59.1 \%$, diikuti dengan perkara penganiayaan sebanyak 51 perkara dengan persentase $14.1 \%$ menempati urutan kedua sedangkan perkara kesusilaan sebanyak 31 perkara dengan prosentase $8.6 \%$ menempati urutan ketiga. Kemudian perkara yang lain seperti perkara narkotika dan pemerasan, masing-masing sebanyak 11 perkara atau $3.2 \%$, perkara pembunuhan dan uang palsu, masing-masing sebanyak 2 perkara atau $0.6 \%$, perkara perjudian sebanyak 7 perkara atau $1.9 \%$, perkara penipuan sebanyak 6 perkara atau $1.7 \%$, perkara penggelapan, kesalahan menyebabkan dan penghinaan masing-masing 3 perkara dengan persentase $0.8 \%$, perkara melarikan perempuan di bawah umur sebanyak 4 perkara atau $11 \%$. Sedangkan perkara yang paling sedikit adalah perkara senjata tajam yaitu sebanyak 1 perkara atau $0.2 \%$.

Putusan Hakim terhadap klien anak paling banyak sejumlah 80 orang terdiri dari putusan yang berupa pidana 3 bulan sebanyak 19 orang dengan persentase $23.8 \%$ menempati urutan pertama, pidana 5 bulan sebanyak 10 orang atau $12.5 \%$ menempati urutan kedua dan yang menempati urutan ketiga adalah perdamaian dan pidana 1 bulan yang masing-masing sebanyak 8 orang. Kemudian untuk putusan Hakim yang lain E-ISSN: 2657-0300 Lembaga Penelitian dan Penerbitan Hasil Penelitian Ensiklopedia 285 
berupa pidana bersyarat sebanyak 7 orang atau $8.8 \%$, pidana 2 bulan dan pidana 4 bulan, masing-masing 6 orang, pidana 6 bulan sebanyak 5 orang atau $6.2 \%$, pidana 7 bulan, pidana 10 bulan dan pidana1 tahun masing-masing sebanyak 2 orang atau 2.5 $\%$, pidana 4 tahun sebanyak 3 orang atau $3.8 \%$. Sedangkan putusan Hakim yang paling sedikit berupa pidana 9 tahun sebanyak 1 orang atau $1.2 \%$. Dalam praktik pelaksanaanya, ada beberapa hambatan yang dijumpai, antara lain : Tidak semua korban atau keluarga korban mau menerima cara penyelesaian non ligitasi. Pihak korban umumnya menghendaki agar pelaku jera jika dimasukkan penjara. Seperti yang dikemukakan salah seorang korban : "kok enak banget dia (pelaku) tidak dipenjara, mau dikasih uang berapa juga saya tidak terima." Kejahatan yang dilakukan pelaku merupakan kejahatan yang diancam dengan pidana yang berat. Faktor penegak hukum yang kurang mendukung untuk adanya perdamaian. Tidak ada petunjuk pelaksanaan (juklak) atau petunjuk teknis (juknis) bagi aparat penegak hukum untuk mengimplementasikan cara penyelesaian secara non-litigasi.

Walaupun cara non-litigasi bisa membuat anak pelaku tindak pidana terhindar dari berbagai efek buruk sanksi pidana, namun ternyata tak semua pihak menyepakatinya. Dalam praktik pelaksanaannya masih dijumpai ada kelemahan sehingga kadang-kadang tidak sesuai dengan tujuan yang diharapkan. Menurut Muladi, model yang cocok untuk sistem peradilan pidana Indonesia adalah yang mengacu kepada daad-dader strafrecht yang disebutnya sebagai model keseimbangan kepentingan. Model ini adalah model yang realistis yaitu yang memperhatikan berbagai kepentingan yang harus dilingkungi oleh hukum pidana, yaitu kepentingan negara, kepentingan umum, kepentingan individu, kepentingan pelaku tindak pidana dan kepentingan korban kejahatan.

Mengacu pada pendapat Muladi seperti tersebut di atas maka penyelesaian secara non litigasi bagi anak yang melakukan tindak pidana merupaka solusi yang bisa dilakukan. Hal ini bisa merupakan pembaharuan dalam hukum pidana dan merupakan alternatif lain, selain pidana penjara. Disamping itu pemerintah provinsi harus benar benar mengujudkan provinsi sumatera barat sebagai provinsi layak anak dengan memperhatikan lembaga lembaga masyarakat yang peduli terhadap perlindungan anak di Sumatera Barat .

\section{Penutup}

Berdasar hasil penelitian dan pembahasan dapat disimpulkan bahwa bentuk penyelesaian secara kekeluargaan/perdamaian atau non-litigasi adalah dengan cara muyawarah antara pelaku, korban, keluarga pelaku atau keluarga korban serta disaksikan oleh pihak LPA dan Polisi sebagai mediator. Penyelesaian secara kekeluargaan/perdamaian atau non-litigasi dilakukan dengan alasan: menghindari stigmatisasi, pelaku sudah menyadari kesalahannya, pihak korban sudah memperoleh ganti rugi dari pelaku, tindak pidana yang dilakukan pelaku ringan, penyelesaian secara non litigasi dapat memenuhi dan mencapai perlindungan terhadap anak yang melakukan tindak pidana, saling memaafkan antar pelaku dan korban, anak pelaku tindak pidana kembali ke orang tua, tercapai keseimbangan dalam masyarakat, sudah tidak ada stigma bagi anak. Namun demikian, penyelesaian non-litigasi ini juga memiliki beberapa kendala dalam praktik pelaksanaannya yakni: pihak korban tidak mau menerima penyelesain secara non litigasi, tindak pidana yang dilakukan diancam dengan pidana berat, aparat penegak hukum kurang mendukung, tidak ada juklak atau 
juknis untuk pelaksanaannya. Bertolak dari hal tersebut di atas, tulisan ini merekomendasikan agar penegak hukum memberikan suasana yang kondusif untuk terjadinya penyelesaian non litigasi. Selain itu dalam bidang legislasi, perlu diwujudkan adanya semacam peraturan pelaksanaan maupun yang bersifat teknis untuk menunjang penyelesaian secara non litigasi ini. Penting pula diperhatikan agar masyarakat tidak memberikan cap buruk terus menerus terhadap anak pelaku tindak pidana. Masyarakat hendaknya menerima anak pelaku tindak pidana, agar ia kembali dapat menemukan ruangnya di dalam masyarakat. Dari kebijakan pemerintah daerah ternyata lebih dominan dalam segala kebijakan, walaupun dalam regulasinya pemerintaah itu adalah fasilitator dalam upaya upaya kesejahteraan Sosial tetapi dalam prakteknya justru pemerinth adalah eksekutor dalam pelaksanaan kesejaahteraan Sosial terutama dalam upaaya perlindungan anak. Dari kesimpulan diatas maka penulis dalam hal ini menyarankan agar penyelesaian perkara terhadap anak terutama anak yang berhadapan dengan hukum atu yang disebut dengan $\mathrm{ABH}$ lebih mendahukan proses diversi atau penyelesai perkara pidana diluar proses pengadilan, dan LPA Sumatera Barat dapat lebih meningkatkan perannya dalam mendorong penegak hukum menerapkan prinsip prinsip terbaik untuk anak.

\section{Daftar Pustaka}

Atmasasmita, Romli, 2006, Sistem Peradilan Pidana Perseptif Eksistensialisme dan Abolisionisme, Bina Cipta, Bandung 2013, Problem Kenakalan Anak-anak Remaja, Armico, Bandung

Bogdan, Robert dan Steven J Tylor, 2013, Dasar-dasar Penelitian Kualitatif, Usaha Nasional, Cetakan Kedua, Surabaya

Didik M. Arief Mansur dan Elisatris Gultom, 2017, Urgensi Perlindungan Korban Kejahatan, Raja Grafindo, Jakarta

Harkrisnowo, Harkristuti, 2013, Rekonstruksi Konsep Pemidanaan : Suatu GugatanTerhadap Proses Legislasi dan Pemidanaan di Indonesia, Orasi pada upacara pengukuhan Guru Besar Tetap dalam Hukum Pidana, FH UI, Jakarta

Hadisuprapto,Paulus, 2013, Pemberian Malu Reintegratif sebagai Sarana Non penal Penanggulangan Perilaku Delikuen Anak, Disertasi Program Doktor Ilmu Hukum Universitas Diponegoro, Semarang

Hanitijo Soemitro, Ronny, 2019, Metodologi Penelitian Hukum, Grafika,Jakarta

Laurensius, S., Situngkir, D., Putri, R., \& Fauzi, R. (2018). Cyber Bullying Against Children In Indonesia. In International Conference on Social Sciences, Humanities, Economics and Law. European Alliance for Innovation (EAI).

Muladi, 2002, Kapita Selekta Hukum Pidana, Universitas Diponegoro, Semarang Iswanto dan Angkasa, 2002, Diktat Viktimologi, Fakultas Hukum Unsoed, Purwokerto Nawawi Arief,Barda, 2004, Kebijakan Legislatif dalam Penanggulangan Kejahatan dengan Pidana Penjara,

-, 2008, Beberapa Aspek Kebijakan Penegakan Hukum dan Pengembangan Hukum Pidana, Citra Aditya Bakti, Bandung

$\longrightarrow$, 2001, Masalah Penegakan Hukum dan Kebijakan Penanggulangan Kejahatan, Citra Aditya Bakti, Bandung

Peter M. Blau dan Marshall W. Meyer, 2007, Birokrasi dalam Masyarakat Modern, UI Press, Jakarta

Reksodiputro, Mardjono, 2013, Sistem Peradilan Pidana (Melihat kepada Kejahatan dan Penegakan Hukum dalam Batas-batas Toleransi), Pidato Pengukuhan 
Penerimaan Guru Besar dalam Ilmu Hukum pada Fakultas Hukum Universitas Indonesia, Jakarta , 2004, Sistem Peradilan Pidana (Tugas dan Fungsi Penegak Hukum MelawanKejahatan) dalam Hak Asasi Manusia Dalam Sistem Peradilan Pidana, Pusat Pelayanan Keadilan dan Pengabdian Hukum UI, Jakarta

R.M.Jackson, 2002, Enforcing the Law, Pelican Book

Susanto, I. S., 2002, Diktat Kriminologi, Fakultas HukumUNSOED, Purwokerto Sudarto, 2010, Kapita Selekta Hukum Pidana, Alumni, Bandung Soekanto,Soerjono, 2008, Remaja Karya, Bandung Soetodjo, Wagiati,2006, Hukum Pidana Anak, Refika Aditama, Bandung 